\title{
COVID-19 Pandemi Sürecinde Gençlerin Medya Okuryazarlık Düzeylerinin Çeşitli Değişkenler Açısından İncelenmesi
}

Öz

Medya okuryazarlığı ve dijital okuryazarlık, içinde yaşadığımız dijital teknoloji çağında ihtiyaç duyulan 21 . yüzyıl becerileri arasında yer almaktadır. Medya okuryazarlığı ve dijital okuryazarlık CoviD-19 pandemi sürecinin de etkisiyle günümüz eğitim uygulamaları için anahtar bir beceri olarak değerlendirilebilir. Araştırma gençlerin medya okuryazarlık düzeylerinin belirlenmesi ve çeşitli değişkenlere göre incelenmesi amacıyla yapılmıştır. Yöntem olarak nicel araştırma desenin kullanıldığı araştırmanın örneklem grubunda 188 genç yer almaktadır. Araştırma verileri Kişisel Bilgi Formu ve Yeni Medya Okuryazarlık Ölçeği kullanılarak elde edilmiştir. Verilerin analizinde Mann Whitney U Testi, Kruskal Wallis Testi ve Tamhane Post Hoc testleri yapılmıştır. Elde edilen sonuçlar gençlerin medya okuryazarlık düzeylerinin yüksek olduğunu göstermiştir. Gençlerin medya okuryazarlık düzeyleri cinsiyet, yaş, sınıf ve okul türü değişkenlerine göre incelenmiştir. Yapılan inceleme sonucunda gençlerin medya okuryazarlık düzeylerinin cinsiyet, yaş ve sınıf değişkenlerine göre anlamlı farklılık gösterdiği; okul türü değişkenlerine göre ise anlamlı farklılık göstermediği belirlenmiştir. Yapılan araştırmanın gençlerin medya okuryazarlık düzeylerine pandemi sürecinin etkisini de ortaya koyması açısından önemli bir araştırma olduğu ve alana katkı sağlayacağı düşünülmektedir.

Anahtar Kelimeler: COVID 19, Gençler, Medya Okuryazarlığı, Pandemi, Medya.

* Dr. Öğr. Üyesi, Sağlık Bilimleri Üniversitesi, Gülhane Sağlık Bilimleri Fakültesi, Çocuk Gelişimi Bölümü, Ankara Türkiye. alev.ustundag@sbu.edu.tr, ORCID: 0000-0001-5832-6810 


\begin{abstract}
Media and digital literacy are two of the 21st-century skills required in the current age of digital technology in which we live. Given the impact of the COVID-19 pandemic, media and digital literacy are considered key skills for today's educational practices. Following a qualitative design, this study seeks to gauge young people's media literacy levels and to examine them in light of different variables. The sample group consisted of 188 young people. After a personal information form and the New Media Literacy Scale to collect data, we subjected the data obtained to a Mann Whitney U Test, Kruskal Wallis Test, and Tamhane Post Hoc Test for analysis. The findings revealed that young people's media literacy levels are high. Young people's media literacy levels were analyzed by gender, age, grade level, and school type. The findings revealed that young people's media literacy levels differed significantly by gender, age, and grade level but not by school type. This study is important because it sheds light on the impact that the COVID-19 pandemic has had on young people's media literacy levels.
\end{abstract}

Keywords: COVID 19, Youth, Media Literacy, Pandemic, Media.

\title{
Giriş
}

Medya okuryazarlığı; görsel, işitsel ve basılı medya içeriklerine erişebilme, erişilen içerikleri eleştirel bakış açısıyla analiz edip değerlendirebilme ve bireylerin medya içeriklerini üretebilme becerisi olarak tanımlanmaktadır (Üstündağ, 2020). Medya okuryazarlığı ve dijital okuryazarlık, içinde bulunduğumuz 21. yüzyılda ihtiyaç duyulan temel beceriler arasında yer almaktadır (Griffin ve Care, 2015). Bireylerin uzun vadeli öğrenme davranışı geliştirerek, topluma olumlu yönde katkıda bulunmalarını sağlayacak beceri ve bilginin kazandırılmasını ifade eden medya okuryazarlığı, pandemi süreciyle birlikte daha da önem kazanmıştır (Çam ve Kılyıcl, 2017).

Bilgi okuryazarlığı, bilgisayar okuryazarlığı, dijital okuryazarlık, iletişim okuryazarlığı, görsel okuryazarlık, teknolojik okuryazarlık gibi içinde çeşitli okuryazarlık türlerini barındıran medya okuryazarlığı; (Çam ve Kıyıcı, 2017; Skills, 2003) gençlerin dijital teknolojiyle bağlantılı bilgi kaynaklarından yararlanarak, kendilerini günümüz teknolojisine uyarlamalarına yardımcı olmaktadır (Çam ve Kıyıcı, 2017). Medya okuryazarlığı, gençlerin bilgiye erişim becerilerini geliştirmenin yanında, aynı zamanda dijital teknolojinin kullanımı sırasında eleştirel düşünme yetkinliklerini de desteklemektedir (Zulkarnain, Heleni ve Thahir, 2020).

\section{Medya Okuryazarlığının Önemi ve Yararları}

İçinde bulunduğumuz pandemi koşulları bağlamında değerlendirildiğinde medya okuryazarlık becerisinin desteklenmesi ve geliştirilmesindeki başarı, eğitimdeki başarının bir göstergesi olarak değerlendirilmektedir (American Academy of Pediatrics, 2020; Zulkarnain, Heleni ve Thahir, 2020). Salgın sürecince sosyal yaşamdan uzaklaşan gençler medya okuryazarlığı 
becerileri sayesinde dijital teknolojiyi işlevsel kullanma alışkanlığı kazanırken, aynı zamanda daha etkili iletişim kurma, eleştirel düşünme ve yaratıcılığı ön plana çlkaran yetkinlikler kazanabilmektedir (American Academy of Pediatrics, 2020).

Yapılan çalışmalar medya okuryazarlığı becerisi ile etkileşim, farklı kaynakları analiz edebilme, iletişim ve problem çözme becerileri arasında yakın bir ilişki olduğunu ortaya koymaktadır (Zulkarnain, Heleni ve Thahir, 2020). Medya okuryazarlığı gençlerin matematiği anlamalarına ve matematiği pratik bir oyun, rekabet ve uygulama haline getirmelerine yardımcı olmaktadır (Zulkarnain, Heleni ve Thahir, 2020). Hague ve Payton'ın (2010) yaptığı araştırma medya okuryazarlığının gençlerin bilgisini geliştirdiğini, merak ve yaratıcılıklarını teşvik ettiğini, gençlerin çoğunun sosyal medya, e-posta, Skype kullandıklarını ve internette gezinme konusunda iyi becerilere sahip olduklarını göstermektedir (Akbar ve Anggaraeni, 2017; Shopova, 2014). İçinde bulunduğumuz dijital çağ, gençlerin bilim ve teknolojideki gelişmeleri takip ederek, öğrenmenin gençlerin yaşadıkları zamana ve ihtiyaçlarına göre sunulmasını gerekli kılmaktadır.

E-öğrenmeye dayalı çalışmalar 2010 yılından bu yana yürütülmekte olup, pandemi süreci gençlerin medya ve dijital okuryazarlık becerilerini geliştirerek, iyileştirmeleri adına önemli fırsatlar sunmaktadır. E-öğrenme, pandemi nedeniyle günlerinin büyük bölümünü bilgisayar başında geçiren gençler için çevrimiçi bir çalışma ortamı sunarak, eğitmen ve öğrenciler arasında karşılıklı etkileşimin kurulmasına imkân sağlamaktadır (Fahlevi, 2018). Yazdi’nin (2012) ifadesiyle e-öğrenme, bilgi teknolojisine dayalı etkileşimli bir öğrenme ortamı sunarak, geleneksel eğitimin alternatifi olarak karşımıza çıkmaktadır. Yaşadığımız pandemi sürecindeki eğitim uygulamaları bu görüşü destekler niteliktedir.

Pandemi süreci medya teknolojisindeki yenilikleri hızlandırırken, dijital uygulamalar ve kaynaklara olan ihtiyaç katlanarak artmıştır (Zulkarnain, Heleni ve Thahir, 2020). Medyanın bilgiye kolayca erişmeyi sağlaması, bilgi aramayı kolaylaştırması, sosyal ilişkileri kuvvetlendirmesi, içerik oluşturulmasına ve paylaşılmasına olanak tanıması, bu sonuç üzerinde etkili olmaktadır (Simons, Meeus ve T’Sas, 2017).

Medyanın doğru bir şekilde kullanımının, günlük hayata dahil edilebilmesi, belirli bir derecede medya okuryazarlığını gerekli kılmaktadır. Medya okuryazarlığı yetkinliği sayesinde gençler toplumsal olaylara daha duyarlı olarak yaklaşırken, medyadan gelen iletileri doğru bir şekilde değerlendirme, çözümleme ve eleştirel düşünme becerisi kazanmaktadır. Bu noktada ebeveynlerin dışında eğitim kurumlarının da büyük sorumluluğu bulunmaktadır (Simons, Meeus ve T’Sas, 2017). Medya okuryazarlığı bireylere medyayla daha doğru bir şekilde etkileşime geçerek, risklerle nasıl başa çıkacakları noktasında önemli fırsatlar sunmaktadır (Üstündağ, 2020).

\section{Araştırmanın Amacı}

COVID-19 salgını sırasında dijital teknoloji sadece eğitimin sürdürülmesi için değil, gençlerin yaşadıkları kısıtlamalar ve sokağa çıkma yasakları nedeniyle sosyal hayatlarını 
sürdürebilmeleri için de gerekli hale gelmiştir. İzolasyon, kısıtlama ve sosyal mesafe sürecinde gençler, öğrenmek, yaşamak ve bağlantıda kalmak için dijital teknolojiye her zamankinden daha fazla ihtiyaç duyar hale gelmiştir.

Dijital teknoloji, gençler tarafından sosyal, fiziksel, duygusal, entelektüel ve ruhsal refahlarını güçlendirmek ve sürdürmek adına aktif şekilde kullanılmaktadır. COVID-19 salgınının ve etkilerinin bir süre daha etkili olacağı göz önüne alındığında medya okuryazarlığının daha da önem kazanacağı öngörülebilir. Bu nedenle yapılan araştırmada gençlerin medya okuryazarlık düzeylerinin belirlenmesi ve çeşitli değişkenlere göre incelenmesi amaçlanmıştır.

Bu amaç doğrultusunda, aşağıdaki sorulara cevap aranmıştır:

1. Araştırmaya katılan gençlerin medya okuryazarlık düzeyleri nedir?

2. Cinsiyet medya okuryazarlığı için ayırt edici bir değişken midir?

3. Gençlerin medya okuryazarlık düzeyleri yaşa göre farklılık göstermekte midir?

4. Gençlerin medya okuryazarlık düzeyleri sınıf düzeyine göre farklılık göstermekte midir?

5. Gençlerin medya okuryazarlık düzeyleri devam edilen okul türüne göre farklılık göstermekte midir?

\section{Yöntem}

\section{Araştırmanın Modeli}

$\mathrm{Bu}$ çalışma temel nicel araştırma modeliyle oluşturulmuştur. Gençlerin medya okuryazarlık düzeylerinin belirlenmesi ve çeşitli değişkenlere göre incelenmesi amacını sağlayabilecek yöntem olduğu için betimsel araştırma modeli tercih edilmiştir (Metin, 2014).

\section{Araştırmanın Evreni ve Örneklemi}

Araştırmanın evrenini Ankara ili Etimesgut İlçesinde bulunan tüm liseler oluşturmaktadır. Etimesgut İlçe Milli Eğitim Müdürlüğünden alınan bilgiye göre ilçede resmi ve özel 51 genel lise, 47 mesleki ve teknik lise bulunmaktadır. Araştırmanın örneklem grubunda 188 genç yer almaktadır. Örneklem grubunun belirlenebilmesinde, evrende bulunan tüm gençlerin araştırmaya katılma konusunda eşit ihtimalinin bulunması olanağı sağladığı için basit tesadüfi örnekleme yönteminden yararlanılmıştır (Metin, 2014). 
Tablo 1. Örneklem Grubunda Bulunan Gençlerin Genel Bilgileri

\begin{tabular}{|c|c|c|c|c|}
\hline \multirow{2}{*}{ Genel Bilgiler } & \multicolumn{2}{|c|}{ Kız } & \multicolumn{2}{|c|}{ Erkek } \\
\hline & f & $\%$ & f & $\%$ \\
\hline \multicolumn{5}{|l|}{ Yaş } \\
\hline 15 & 18 & 18,8 & 24 & 26,1 \\
\hline 16 & 24 & 25,0 & 24 & 26,1 \\
\hline 17 & 22 & 22,9 & 28 & 304 \\
\hline 18 & 32 & 33,3 & 16 & 17,4 \\
\hline Toplam & 96 & 100,0 & 92 & 100,0 \\
\hline \multicolumn{5}{|l|}{ Sinif } \\
\hline 9 & 26 & 27,1 & 32 & 34,8 \\
\hline 10 & 16 & 16,7 & 16 & 17,4 \\
\hline 11 & 22 & 22,9 & 28 & 30,4 \\
\hline 12 & 32 & 33,3 & 16 & 17,4 \\
\hline Toplam & 96 & 100,0 & 92 & 100,0 \\
\hline \multicolumn{5}{|l|}{ Okul Türü } \\
\hline Anadolu Lisesi & 56 & 58,3 & 38 & 41,3 \\
\hline Mesleki ve Teknik Anadolu Lisesi & 40 & 41,7 & 54 & 58,7 \\
\hline Toplam & 96 & 100,0 & 92 & 100,0 \\
\hline
\end{tabular}

Tablo 1'de görüldüğü üzere örneklem grubunun \%51,06'sı kılardan, \%48,93'ü de erkeklerden oluşmaktadır. Kızların \%18,8'i 15; \%25,0’i 16; \%22,9’u 17 ve \%33,3’ü de 18 yaşındadır. Erkeklerin \%26,1'i 15; \%26,1’i 16; \%30,4’ü 17 ve \%17,4’ü de 18 yaşındadır. Kızların \%27,1’i 9. sınıfa; \%16,7’si 10. sinıfa; \%22,9’u 11. sınıfa ve \%33,3'ü de 12. sinıfa devam etmektedir. Erkeklerin \%34,8'i 9. sınıfa; \%17,4’ü 10. sınıfa; \%30,4’ü 11. sınıfa ve \%17,4’ü de 12. sınıfa devam etmektedir. Kızların \%58,3’ü Anadolu Lisesinde, \%41,7’si de Mesleki ve Teknik Anadolu Lisesinde eğitimini sürdürmektedir. Erkeklerin \%41,3’ü Anadolu Lisesinde, \%58,7'si de Mesleki ve Teknik Anadolu Lisesinde eğitim görmektedir.

\section{Veri Toplama Araçları}

Araştırmanın temel veri toplama aracı Koç ve Barut (2016) tarafından geliştirilmiş olan "Yeni Medya Okuryazarlık Ölçeği”dir. Ölçeğin yanı sıra araştırmacı tarafından hazırlanan "Kişisel Bilgi Formu" da kullanılmıştır. 
Kişisel bilgi formunda; araştırmaya katılan gençlerin genel bilgilerine ilişkin sorulara (cinsiyetleri, yaşları, sınıf düzeyleri, devam ettikleri okul türü gibi yer verilmiştir.

Yeni Medya Okuryazarlık Ölçeği; Koç ve Barut tarafından (2016) gençlerin medya okuryazarlık düzeylerini belirlemek amacıyla geliştirilen, 5’li likert tipinde olan, 35 madde ve 4 alt boyuttan (fonksiyonel tüketim, eleştirel tüketim, fonksiyonel üretim, eleştirel üretim) oluşan bir ölçektir. Ölçeğin güvenirlik katsayısı 0,965 olarak belirlenmiştir (Koç ve Barut, 2016). Yapılan bu araştırmada ölçeğin güvenirlik katsayısı 0,955 olarak tespit edilmiştir.

\section{Verilerin Toplanması}

Araştırmanın veri toplama araçları pandemi süreci nedeniyle Google forms uygulaması kullanılarak çevrimiçi olarak düzenlenmiş ve uygulanmıştır. Etik kurul izni alındıktan sonra Ankara İl Milli Eğitim Müdürlügünden de okullarda uygulama yapılabilmesi için uygulama izni alınmıştır. Daha sonra ilçede bulunan liselere gidilerek müdürleri ile görüşülmüş, araştırmanın içeriği, amacı ve uygulanışı hakkında müdürler bilgilendirildikten sonra, rehberlik servisi ile irtibat kurularak çevrimiçi olarak hazırlanmış ölçek formunun linkinin sınıf gruplarından paylaşılması talep edilmiştir. Araştırmaya katılım gönüllülük esasına dayandırılmıştır ve bu nedenle hem gençlerden hem de ebeveynlerinden çevrimiçi onay formu alınmıştır.

\section{Verilerin Analizi}

Verilerin analizinde SPSS 22 programı kullanılmıştır. Analiz yapılmadan önce Shapiro-Wilk normallik testi yapılmış ve grup ortalamaları normal dağılmadığı için parametrik olmayan testler kullanılarak analizler gerçekleştirilmiştir. Mann Whitney U Testi, Kruskal Wallis testi ve Tamhane Post Hoc testleri yapılmıştır.

\section{Araştırmanın Etik İzni}

Araştırma etik kurallara uygun şekilde gerçekleştirilmiştir. Araştırma için Sağlık Bilimleri Üniversitesi Hamidiye Bilimsel Araştırmalar Etik Kurulu'ndan 05.02.2021 tarihli ve 21/74 sayılı karar numarası ile Etik Kurul Onayı alınmıştır.

\section{Bulgular}

Bulgular araştırmanın alt amaçları kapsamında incelenmiştir. Araştırmaya katılan gençlerin medya okuryazarlık düzeylerinin ölçek alt boyutları ortalaması Tablo 2'de sunulmuştur:

Tablo 2. Gençlerin Medya Okuryazarlık Düzeyleri Ölçek Alt Boyutları Sonuçları

\begin{tabular}{lccccc}
\hline & $\begin{array}{c}\text { Fonksiyonel } \\
\text { Tüketim }\end{array}$ & $\begin{array}{c}\text { Eleştirel } \\
\text { Tüketim }\end{array}$ & $\begin{array}{c}\text { Fonksiyonel } \\
\text { Üretim }\end{array}$ & $\begin{array}{c}\text { Eleştirel } \\
\text { Üretim }\end{array}$ & Toplam \\
\hline $\mathrm{N}$ & 188 & 188 & 188 & 188 & 188 \\
Ortalama & 4,016 & 4,026 & 4,352 & 3,727 & 4,004 \\
Minimum & 1,29 & 2,00 & 1,14 & 2,30 & 1,77 \\
Maximum & 4,86 & 5,00 & 5,00 & 4,60 & 4,80 \\
\hline
\end{tabular}


Yapılan analiz sonucunda örneklem grubunda bulunan gençlerin Yeni Medya Okuryazarlık Ölçeği ortalamalarının 4,004 olduğu belirlenmiştir. Gençlerin ölçek toplam puanlarının yüksekliği, medya okuryazarlık düzeylerinin yüksek olduğunu göstermektedir. Ölçeğin alt boyutları incelendiğinde gençlerin fonksiyonel tüketim $(4,016)$, eleştirel tüketim $(4,026)$ ve eleştirel üretim $(3,727)$ alt boyut düzeylerinin de yüksek, fonksiyonel üretim $(4,352)$ alt boyutu düzeylerinin ise çok yüksek olduğu belirlenmiştir. Gençlerin medya okuryazarlık düzeylerinin cinsiyet değişkenine ilişkin sonuçlar Tablo 3’te sunulmuştur:

Tablo 3. Ölçeğin Cinsiyet Değişkenine İlişkin Mann Whitney U Tesi Sonuçları

\begin{tabular}{|c|c|c|c|c|c|c|c|}
\hline Ölçek alt boyutları & Cinsiyet & $\mathbf{N}$ & $\mathbf{x}$ & SS & $\mathbf{U}$ & $\mathbf{Z}$ & $\mathbf{p}$ \\
\hline \multirow{3}{*}{ Fonksiyonel Tüketim } & $\mathrm{K} 1 \mathrm{Z}$ & 96 & 86,83 & 833 & & & \\
\hline & & & & & 368 & $-2,081$ & ,037 \\
\hline & Erkek & 92 & 102,50 & 943 & & & \\
\hline \multirow{3}{*}{ Eleştirel Tüketim } & $\mathrm{K} ı \mathrm{Z}$ & 96 & 93,67 & 899 & & & \\
\hline & & & & & 433 &,- 217 & ,828 \\
\hline & Erkek & 92 & 95,37 & 877 & & & \\
\hline \multirow{3}{*}{ Fonksiyonel Üretim } & $\mathrm{K} ı \mathrm{Z}$ & 96 & 79,50 & 763 & & & \\
\hline & & & & & 297 & $-3,937$ & ,000 \\
\hline & Erkek & 92 & 110,15 & 101 & & & \\
\hline \multirow{3}{*}{ Eleştirel Üretim } & $\mathrm{K} ı \mathrm{Z}$ & 96 & 89,48 & 859 & & & \\
\hline & & & & & 393 & $-1,305$ & ,192 \\
\hline & Erkek & 92 & 99,74 & 917 & & & \\
\hline \multirow{3}{*}{ Toplam } & $\mathrm{K} ı \mathrm{Z}$ & 96 & 85,79 & 823 & & & \\
\hline & & & & & 358 & $-2,253$ & ,024 \\
\hline & Erkek & 92 & 103,59 & 953 & & & \\
\hline
\end{tabular}

Yapılan analiz sonucunda örneklem grubunda bulunan gençlerin Yeni Medya Okuryazarlık Ölçeği ortalamalarının cinsiyet değişkenine göre anlamlı farklılık gösterdiği belirlenmiştir. Ölçeğin alt boyutlarında değerlendirme yapıldığında ise fonksiyonel tüketim ve fonksiyonel üretim alt boyutlarında erkek öğrencilerin lehine anlamlı farklılık olduğu belirlenmiştir. Gençlerin medya okuryazarlık düzeylerinin yaş değişkenine ilişkin sonuçlar Tablo 4’te sunulmuştur: 
Tablo 4. Ölçeğin Yaş Değişkenine İlişkin Kruskal Wallis Sonuçları

\begin{tabular}{|c|c|c|c|c|c|c|c|}
\hline Ölçek alt boyutları & Yaş & $\mathbf{N}$ & $\mathbf{x}$ & $\begin{array}{l}\text { Chi- } \\
\text { Square }\end{array}$ & df & p & $\begin{array}{l}\text { Anlamlı } \\
\text { Fark }\end{array}$ \\
\hline \multirow{4}{*}{ Fonksiyonel Tüketim } & 15 & 42 & 75,50 & \multirow{4}{*}{22,834} & \multirow{4}{*}{3} & \multirow{4}{*}{,000 } & \multirow{4}{*}{$\begin{array}{c}15 \text { il } 16 \\
16 \text { ile } 17\end{array}$} \\
\hline & 16 & 48 & 1111,00 & & & & \\
\hline & 17 & 50 & 76,70 & & & & \\
\hline & 18 & 48 & 113,17 & & & & \\
\hline \multirow{4}{*}{ Eleştirel Tüketim } & 15 & 42 & 71,79 & \multirow{4}{*}{51,314} & \multirow{4}{*}{3} & \multirow{4}{*}{,000 } & \multirow{4}{*}{$\begin{array}{c}15 \text { ile hepsi } \\
16 \text { ile } 17 \\
17 \text { ile } 18\end{array}$} \\
\hline & 16 & 48 & 109,00 & & & & \\
\hline & 17 & 50 & 63,50 & & & & \\
\hline & 18 & 48 & 132,17 & & & & \\
\hline \multirow{4}{*}{ Fonksiyonel Üretim } & 15 & 42 & 134,93 & \multirow{4}{*}{91,265} & \multirow{4}{*}{3} & \multirow{4}{*}{,000 } & \multirow{4}{*}{$\begin{array}{l}15 \text { ile } 17 \\
\text { ve } 18 \\
16 \text { ile } 17 \\
17 \text { ile } 18\end{array}$} \\
\hline & 16 & 48 & 117,75 & & & & \\
\hline & 17 & 50 & 36,14 & & & & \\
\hline & 18 & 48 & 96,67 & & & & \\
\hline \multirow{4}{*}{ Toplam } & 15 & 42 & 104,64 & \multirow{4}{*}{52,116} & \multirow{4}{*}{3} & \multirow{4}{*}{,000 } & \multirow{4}{*}{$\begin{array}{l}15 \text { ile } 16 \\
\text { ve } 17 \\
16 \text { ile } 17 \\
17 \text { ile } 18\end{array}$} \\
\hline & 16 & 48 & 114,50 & & & & \\
\hline & 17 & 50 & 47,58 & & & & \\
\hline & 18 & 48 & 114,50 & & & & \\
\hline
\end{tabular}

Yapılan analiz sonucunda örneklem grubunda bulunan gençlerin Yeni Medya Okuryazarlık Ölçeği ortalamalarının yaşa göre farklılık gösterdiği belirlenmiştir $(p=, 000)$. Farkın hangi gruptan kaynaklandığını belirleyebilmek için yapılan post hoc testi sonucunda farklılığın 17 yaş grubundan kaynaklandığı belirlenmiştir. Grup ortalamaları karşılaştırıldığında diğer yaş gruplarının ölçek ortalamaları yüksekken, 17 yaş grubunun ortalamasının düşük olduğu belirlenmiştir. 17 yaş grubunun aleyhinde bir farklılık olduğu görülürken, ölçeğin alt boyutlarında yapılan analizde tüm alt boyutlarında da yaş değişkenine göre farklılığın olduğu belirlenmiştir. Fonksiyonel tüketim alt boyutunda 15 ile 16 yaş grupları arasında 16 yaş grubunun lehine; 16 ile 17 yaş grupları arasında 16 yaş grubunun lehine anlamlı farklılık bulunmuştur. Eleştirel tüketim alt boyutunda 15 ile diğer yaş grupları arasında 16 ve 18 yaş gruplarının lehine; 16 ile 17 yaş grupları arasında 16 yaş grubunun lehine; 17 ile 18 yaş grupları arasında 18 yaş grubunun lehine anlamlı farklılık bulunmuştur. Fonksiyonel üretim alt boyutunda 15 ile 17 ve 18 yaş grupları arasında 15 yaş grubunun lehine ve 16 ile 17 yaş grupları arasında 16 yaş grubunun lehine anlamlı farklılık bulunmuştur. Eleştirel üretim alt boyutunda 15 ile 17 ve 18 yaş grupları arasında 15 yaş grubunun lehine; 16 ile 17 yaş grupları arasında 16 
yaş grubunun lehine; 18 ile 17 yaş grupları arasında 18 yaş grubunun lehine anlamlı farklılık bulunmuştur. Gençlerin medya okuryazarlık düzeylerinin sınıf değişkenine ilişkin sonuçlar Tablo 5'te sunulmuştur:

Tablo 5. Ölçeğin Sınıf Değişkenine İlişkin Kruskal Wallis Sonuçları

\begin{tabular}{|c|c|c|c|c|c|c|c|}
\hline Ölçek alt boyutları & Sinif & $\mathbf{N}$ & $\mathbf{x}$ & $\begin{array}{l}\text { Chi- } \\
\text { Square }\end{array}$ & df & p & $\begin{array}{l}\text { Anlamlı } \\
\text { Fark }\end{array}$ \\
\hline \multirow{4}{*}{ Fonksiyonel Tüketim } & 9 & 58 & 85,29 & \multirow{4}{*}{17,350} & \multirow{4}{*}{3} & \multirow{4}{*}{,001 } & \multirow{4}{*}{10 ile 11} \\
\hline & 10 & 32 & 111,00 & & & & \\
\hline & 11 & 50 & 76,70 & & & & \\
\hline & 12 & 48 & 113,17 & & & & \\
\hline \multirow{4}{*}{ Eleştirel Tüketim } & 9 & 58 & 82,05 & \multirow{4}{*}{45,747} & \multirow{4}{*}{3} & \multirow{4}{*}{,000 } & \multirow{4}{*}{$\begin{array}{l}9 \text { ile } 11 \text { ve } 12 \\
\quad 10 \text { ile } 11 \\
11 \text { ile } 12\end{array}$} \\
\hline & 10 & 32 & 109,00 & & & & \\
\hline & 11 & 50 & 63,50 & & & & \\
\hline & 12 & 48 & 132,17 & & & & \\
\hline \multirow{4}{*}{ Fonksiyonel Üretim } & 9 & 58 & 119,50 & \multirow{4}{*}{58,298} & \multirow{4}{*}{3} & \multirow{4}{*}{,000 } & \multirow{4}{*}{$\begin{array}{l}9 \text { ile } 11 \text { ve } 12 \\
10 \text { ile } 11\end{array}$} \\
\hline & 10 & 32 & 118,00 & & & & \\
\hline & 11 & 50 & 47,26 & & & & \\
\hline & 12 & 48 & 97,83 & & & & \\
\hline \multirow{4}{*}{ Eleştirel Üretim } & 9 & 58 & 130,19 & \multirow{4}{*}{90,088} & \multirow{4}{*}{3} & \multirow{4}{*}{,000 } & \multirow{4}{*}{$\begin{array}{l}9 \text { ile } 11 \text { ve } 12 \\
10 \text { ile } 11 \\
11 \text { ile } 12\end{array}$} \\
\hline & 10 & 32 & 117,75 & & & & \\
\hline & 11 & 50 & 36,14 & & & & \\
\hline & 12 & 48 & 96,67 & & & & \\
\hline \multirow{4}{*}{ Toplam } & 9 & 58 & 107,36 & \multirow{4}{*}{51,732} & \multirow{4}{*}{3} & \multirow{4}{*}{,000 } & \multirow{4}{*}{11 ile hepsi } \\
\hline & 10 & 32 & 114,50 & & & & \\
\hline & 11 & 50 & 47,58 & & & & \\
\hline & 12 & 48 & 114,50 & & & & \\
\hline
\end{tabular}

Yapılan analiz sonucunda örneklem grubunda bulunan gençlerin Yeni Medya Okuryazarlık Ölçeği ortalamalarının sınıf değişkenine göre farklılık gösterdiği belirlenmiştir $(p=, 000)$. Farkın hangi gruptan kaynaklandığını belirleyebilmek için yapılan post hoc testi sonucunda farklılığın 11. sınıftan kaynaklandığı belirlenmiştir. Grup ortalamaları karşılaştırıldığında diğer sınıf düzeylerinin ölçek ortalamaları yüksekken, 11. sınıfın ortalamasının düşük olduğu belirlenmiştir. Ölçeğin alt boyutlarında yapılan tüm alt boyutlarında da sınıf değişkenine göre anlamlı farklılığın olduğu belirlenmiştir. Fonksiyonel tüketim alt boyutunda 10. ile 11. sınıf arasında 10. sınıfın lehine anlamlı farklılık bulunmuştur. Eleştirel tüketim alt boyutunda 9 ile 
11 arasında 9 sinıfın lehine; 9 ile 12 arasında 12 sinıfın lehine; 10. ile 11. sinıf arasında 10. sinıfın lehine; 11. ile 12. sınıf arasında 12. sınıfın lehine anlamlı farklılık bulunmuştur. Fonksiyonel üretim alt boyutunda 11. 12. sinıf ile 9. sinıf arasında 9. sinıfın lehine; 10. ile 11. sinıf arasinda 10. sınıfın lehine anlamlı farklılık bulunmuştur. Eleştirel üretim alt boyutunda 9. ile 11. Ve 12 sınıf arasında 9. sinıfın lehine; 10. ile 11. sinıf arasında 10. sinıfın lehine; 12. ile 11. sinıf arasında 12. sınıfın lehine anlamlı farklılık bulunmuştur. Gençlerin medya okuryazarlık düzeyleri sınıf düzeyine göre farklılık göstermektedir. Gençlerin medya okuryazarlık düzeylerinin okul türü değişkenine ilişkin sonuçlar Tablo 6'da sunulmuştur:

Tablo 6. Ölçeğin Okul Türü Değişkenine İlişkin Mann Whitney U Tesi Sonuçları

\begin{tabular}{|c|c|c|c|c|c|c|c|}
\hline $\begin{array}{l}\text { Ölçek alt } \\
\text { boyutları }\end{array}$ & Okul Türü & $\mathbf{N}$ & $\mathbf{X}$ & SS & $\mathbf{U}$ & $\mathbf{Z}$ & $\mathbf{p}$ \\
\hline \multirow{3}{*}{$\begin{array}{l}\text { Fonksiyonel } \\
\text { Tüketim }\end{array}$} & Anadolu Lisesi & 94 & 96,35 & 9057,00 & \multirow{3}{*}{4244,000} & \multirow{3}{*}{,- 492} & \multirow{3}{*}{,623 } \\
\hline & & & & & & & \\
\hline & $\begin{array}{c}\text { Mesleki ve Teknik } \\
\text { Anadolu Lisesi }\end{array}$ & 32 & 111,00 & 8709,00 & & & \\
\hline \multirow{2}{*}{$\begin{array}{l}\text { Eleştirel } \\
\text { Tüketim }\end{array}$} & Anadolu Lisesi & 94 & 94,69 & 8901,00 & \multirow{2}{*}{4400,000} & \multirow{2}{*}{,- 049} & \multirow{2}{*}{,961 } \\
\hline & $\begin{array}{c}\text { Mesleki ve Teknik } \\
\text { Anadolu Lisesi }\end{array}$ & 94 & 94,31 & 8865,00 & & & \\
\hline \multirow{2}{*}{$\begin{array}{l}\text { Fonksiyonel } \\
\text { Üretim }\end{array}$} & Anadolu Lisesi & 94 & 92,78 & 8721,00 & \multirow{2}{*}{4256,000} & \multirow{2}{*}{,- 443} & \multirow{2}{*}{,658 } \\
\hline & $\begin{array}{l}\text { Mesleki ve Teknik } \\
\text { Anadolu Lisesi }\end{array}$ & 94 & 96,22 & 9045,00 & & & \\
\hline \multirow{2}{*}{$\begin{array}{l}\text { Eleştirel } \\
\text { Üretim }\end{array}$} & Anadolu Lisesi & 94 & 93,69 & 8807,00 & \multirow{2}{*}{4342,000} & \multirow{2}{*}{,- 206} & \multirow{2}{*}{,837 } \\
\hline & $\begin{array}{c}\text { Mesleki ve Teknik } \\
\text { Anadolu Lisesi }\end{array}$ & 94 & 95,31 & 8959,00 & & & \\
\hline \multirow{3}{*}{ Toplam } & Anadolu Lisesi & 94 & 94,35 & 8869,00 & \multirow{3}{*}{4404,000} & \multirow{3}{*}{,- 038} & \multirow{3}{*}{,970 } \\
\hline & & & & & & & \\
\hline & $\begin{array}{l}\text { Mesleki ve Teknik } \\
\text { Anadolu Lisesi }\end{array}$ & 94 & 94,65 & 8897,00 & & & \\
\hline
\end{tabular}

Yapılan analiz sonucunda örneklem grubunda bulunan gençlerin Yeni Medya Okuryazarlık Ölçeği ortalamalarının devam edilen okul türüne göre hem toplamda hem de alt boyut düzeyinde farklılaşmadığı belirlenmiştir. Gençlerin medya okuryazarlık düzeyleri devam edilen okul türüne göre farklllık göstermemektedir. 


\section{Tartışma}

2020 yılından bu yana yaşadığımız pandemi süreci nedeniyle karantina uygulamaları neticesinde ekran karşısında daha fazla vakit geçirilmeye başlanmıştır. Eğitimin ve çalışma hayatının uzaktan olmasının da bu durum üzerinde etkileri bulunmaktadır. Beklenmeyen bir durum ile karşı karşıya kalındığı için toplumun her kesiminde tüm bireyler hem eğitim, iş, hem de sosyal hayatını internet aracılığıyla gidermeye başlamıştır. Eski normal koşullar sırasında ekran kullanımının gençlerin sağlığı ve gelişimi üzerindeki olumsuz etkileri konusunda sınırlandırma ve eğitim çalışmaları sürdürülürken, şimdi gençlerin tüm hayatı ekrana sığdırılmış haldedir. Yoğun olarak dijital medya kullanımı söz konusudur. Bu nedenle bu araştırmada gençlerin medya okuryazarlık düzeylerinin belirlenmesi ve çeşitli değişkenlere göre incelenmesi amaçlanmıştır. Elde edilen sonuçlar örneklem grubunda bulunan gençlerin medya okuryazarlık düzeylerinin yüksek olduğunu göstermiştir. Cinsiyet değişkeni açısından yapılan incelemede gençlerin medya okuryazarlık düzeylerinin cinsiyete göre farklılık gösterdiği belirlenmiştir. Yaş değişkeni açısından yapılan incelemede gençlerin medya okuryazarlık düzeylerinin yaşa göre farklılık gösterdiği belirlenmiştir. Sınıf değişkeni açısından yapılan incelemede gençlerin medya okuryazarlık düzeylerinin sınıf düzeyine göre farklılık gösterdiği görülmüştür. Okul türü değişkeni açısından yapılan incelemede gençlerin medya okuryazarlık düzeylerinin devam edilen okul türüne göre farklılık göstermediği belirlenmiştir.

Örneklem grubunda bulunan gençlerin medya okuryazarlık düzeylerinin yüksek oluşu olumlu bir sonuç olarak değerlendirilmektedir. Yaşanan pandemi süreci birçok belirsizliği ve bilgi kirliliğini beraberinde getirirken, gençlerin medya okuryazarlık düzeylerinin yüksek oluşu; doğru bilgiye ulaşma, medya içeriklerini anlama, anlamlandırma ve yorumlama becerilerinin yüksek olması açısından önem taşımaktadır. Bergsma ve Carney (2008) araştırmalarında olumsuz sağlık davranışlarının değiştirilmesi, iyileştirilmesi ve gençlerin sağlıklarını geliştirme stratejileri oluşturabilmeleri için medya okuryazarlığı becerilerinin yüksek olması gerektiğini vurgulamışlardır. Bu bağlamda değerlendirildiğinde, gençlerin medya okuryazarlık düzeylerinin yüksek oluşunun sağlık davranışları konusunda da bilinçli olmalarına katkısı olabileceği ifade edilebilir.

Araştırmada gençlerin medya okuryazarlık düzeylerinin cinsiyete göre farklılık gösterdiği belirlenmiştir. Erkeklerin medya okuryazarlık düzeyinin kızlardan daha yüksek olduğu görülmüştür. Literatür incelendiğinde Budden ve arkadaşları (2007), Tutkun (2013), Aslan ve arkadaşları (2019) ve Yazgan (2013) tarafından yapılan araştırma sonuçlarında da medya okuryazarlığı düzeyinin cinsiyetler açısından farklılık gösterdiği sonucuna ulaşılmıştır. Elde edilen bulgu, bu bağlamda literatür ile uyumluluk göstermektedir. Ancak literatürde cinsiyet değişkenine göre anlamlı farklılıkların bulunmadığı araştırmalar da mevcuttur (Banaz, 2017; Fidan, 2013; Kartal, 2013; Ylldırım, 2017). Gençlerin özellikle pandemi nedeniyle daha fazla 
ekran karşısında olmasının sonuç üzerinde etkili olduğu düşünülmektedir. Ayrıca uzaktan eğitim uygulamaları nedeniyle gençler derslerini, ödevlerini ve araştırmalarını genellikle dijital teknoloji araçlarını kullanarak gerçekleştirmektedir. Cinsiyet bağlamında farklılık olmasına karşın gençlerin medya okuryazarlığı düzeyinin yüksek olması olumlu bir sonuç olarak değerlendirilebilir.

Araştırmada gençlerin medya okuryazarlık düzeylerinin sınıf düzeyine göre farklılık gösterdiği belirlenmiştir. Yapılan araştırmalar incelendiğinde de benzer şekilde öğrencilerin sınıf düzeyleri ile medya okuryazarlık düzeyleri arasında anlamlı bir fark bulunduğu görülmektedir (Güven, 2014; Özer, Çelik ve Özatll, 2021; Semiz, 2013; Som ve Kurt, 2012). Gençlerin yaşları arttıkça bilişsel gelişim düzeyleri de yetişkin seviyesine ulaşmaya başlamaktadır. Bu bağlamda değerlendirildiğinde gençlerin sınıf düzeyleri arasında farklılığın bulunması ve sınıf düzeyi arttıkça da medya okuryazarlığı düzeyinin artması beklenen ve olası bir sonuç olarak değerlendirilmektedir. Elde edilen sonuçlar, gençlerin medya okuryazarlık düzeylerinin yaşa göre de farklılık gösterdiğini ortaya koymaktadır. Yaş değişkeninde okuryazarlık düzeyinin farklılaşmasında gençlerin bu konuda aldıkları eğitimin ve farkındalıklarının artmasının olumlu bir etkisi olabileceği düşünülmektedir.

Literatür incelendiğinde Özer, Çelik ve Özatlı (2021) tarafından yapılan araştırmada okul türüne göre lise öğrencilerinin medya okuryazarlık düzeyinin farklılaştığı sonucuna ulaşılmış olsa da yapılan araştırmada gençlerin medya okuryazarlık düzeylerinin devam edilen okul türüne göre farklılık göstermediği belirlenmiştir. Pandemi öncesine kadar imkanlar dahilinde teknolojik araçların kullanımı söz konusuyken son bir yılda sürekli medya araçlarının kullanımı ile hayatın sürdürülmesinin okul türü değişkeni açısından da farklılığın ortadan kalkmasında etkili olduğu düşünülmektedir. Gençlerin hem eğitim hem de sosyal hayatlarını sürdürebilmek için medya araçlarını kullanmak zorunluluğunun bulunmasının sonuç üzerinde etkili olduğu söylenebilir.

\section{Sonuç ve Öneriler}

Yapılan araştırma gençlerin medya okuryazarlık düzeylerine pandemi sürecinin etkisini ortaya koyması açısından önemli bir çalışma olarak görülmekte ve alana katkı sağlayacağı düşünülmektedir. Elde edilen sonuçlar gençlerin medya okuryazarlık düzeylerinin yüksek olduğunu göstermektedir. Medya okuryazarlığı anlama, analiz etme, kavrama, çıkarımda bulunma, eleştirel düşünme gibi birçok bilişsel beceri gerektirdiği için gençlerin sonuçlarının yüksek olmasının önemli bir bulgu olduğu düşünülmektedir.

Elde edilen sonuçlar doğrultusunda; gençlerin ekran karşısında geçirdikleri süreyi daha verimli hale getirebilecekleri yaratıcı projeler oluşturmaları için okul-aile iş birlikleri kurulabilir. Uzaktan eğitim süreci devam ederken medya okuryazarlığı mevcut eğitim programına çeşitli 
şekillerde dahil edilebilir (Friesemn 2013; Friesem ve diğerleri 2014; Neag 2015). Örneğin; öğretmenler belirli konuların içeriğini kullanarak gençlerin medya okuryazarlığı becerilerini geliştirebilirler. Medya okuryazarlığı, görsel ve işitsel okuryazarlık becerisi gerektirdiği için sanat ve müzik derslerinde kullanılabilir. Çeşitli metin içeriklerini okuma ve anlama becerisi gerektirdiğinde medyanın iletişimsel işlevine odaklanılan çalışmalar ya da ödevler hazırlanabilir. Gençlerin doğru bilgiye ulaşması, araması, analiz etmesi ve sunmasını sağlayacak tarih, coğrafya gibi sosyal bilimlerde medya okuryazarlığını geliştirme olanakları sağlanabilir (Üstündağ, 2020).

Pandemi süreci nedeniyle ulaşılabilen genç sayısı kısıtlı olmuştur. Bu nedenle daha geniş kitlelerle benzer araştırma tekrarlanabilir. Farklı yaş gruplarını analiz eden araştırmalar yapılabilir. Ebeveynlerin medya okuryazarlık ve eğitim düzeyleri ile çocuklarının medya okuryazarlık düzeylerinin karşılaştırıldığı araştırmalar tasarlanabilir. 


\section{Media Literacy In Young People During The COVID-19 Pandemic In Light of Different Variables}

Alev Üstündağ*

\section{Introduction}

Media and digital literacy are two of the 21st-century skills required in today's age of digital technology. Media and digital literacy are considered vital skills in today's educational practices given the impact that the COVID-19 pandemic has at on education. Media literacy includes diverse types of literacy, such as information literacy, computer literacy, digital literacy, communication literacy, visual literacy, and technological literacy. When evaluated in the context of the ongoing pandemic, success in supporting and developing media literacy skills is regarded as an indicator of educational success. Therefore, media literacy during the pandemic can be interpreted as young people's ability to make proficient use digital devices. Young people can therefore find information using different types of media, think critically, exercise their creativity, collaborate with others, and communicate effectively all while observing media safety guidelines.

Digital technology played an essential role in not only in allowing education to continue during the COVID-19 pandemic but also in aiding young people to maintain their social lives in the face of social restrictions and mandated curfews. Dealing with isolation, movement restrictions, and social distancing, young people depended on digital technology to learn and stay connected with their peers. Digital technology was and continues to be actively used by young people to strengthen and maintain their social, physical, emotional, intellectual, and spiritual wellbeing. Given that the COVID-19 is expected to continue for a long time, media literacy and guiding young people, especially in using media properly, have risen in importance. Consequently, this

\footnotetext{
* Asst. Prof. (PhD), Universtiy of Health Sciences, Gülhane Health Sciences Faculty, Departmant of Child Development,
} Ankara, Turkey. alev.ustundag@sbu.edu.tr, ORCID: 0000-0001-5832-6810 
study has aimed to determine young people's media literacy levels and to examine them in light of different variables.

To this end, we sought answers to the following questions:

1. Do the young people involved in this study have high media literacy levels?

2. Do young people's media literacy levels differ by gender?

3. Do young people's media literacy levels differ by age?

4. Do young people's media literacy levels differ by grade level?

5. Do young people's media literacy levels differ by the type of school attended?

\section{Method}

\section{Research Model}

This study followed a basic quantitative research design.

\section{Sample group}

A total of 188 young people composed the study's sample group.

\section{Data Collection Tools}

We used the 5-point Likert-type New Media Literacy Scale developed by Koç and Barut (2016) to collect data This scale was composed of thirty-five items and four sub-dimensions (i.e., functional consumption, critical consumption, functional production, critical production). The reliability coefficient of this scale was 0.965 .

\section{Data Collection and Analysis}

The participants completed the New Media Literacy Scale online as a Google Form. After collecting and organizing data, we used the Mann Whitney U Test, Kruskal Wallis Test, and Tamhane Post Hoc Tests to analyze study data.

\section{Findings}

The findings reveal that young people have high levels of media literacy. We analyzed media literacy levels by gender, age, grade level, and school type. As a result of our analyses, we found that young people's media literacy levels differed significantly by gender, age, and grade level, but not by school type.

\section{Suggestions}

In line with the study's findings, we recommend that programs encouraging schools and families to collaborate with each other be established. These programs should provide young people the opportunity to realize creative projects so as to transform the time they spend in front of a screen into a productive endeavor. Since, however, the number of young people able to be reached was limited because of the pandemic, we recommend that similar studies be carried out with larger numbers of participants. Finally, studies comparing parents' media literacy and education levels with those of their children can also be designed. 


\section{Kaynakça/References}

- $\quad$ Akbar, M. F., \& Anggaraeni, F. D. (2017). Teknologi dalam pendidikan: Literasi digital dan self-directed learning pada mahasiswa skripsi. Indigenous: Jurnal Ilmiah Psikologi, 2(1), 28-38. https://doi. org/10.23917/indigenous.v1i1.4458

- American Academy of Pediatrics. (2020). COVID-19 clinical guidance. Q \& A. Retrieved from https:// services.aap.org/en/pages/covid-19-clinical-guidance-q-a/.

- $\quad$ Aslan, A., Turgut, Y. E., Göksu, İ. ve Aktı Aslan, S. (2019). Çocukların medya okuryazarlık düzeylerinin ve kullanım alışkanlıklarının demografik değişkenler açısından incelenmesi. Gazi University Journal of Gazi Educational Faculty (GUJGEF), 39(2), 793-815

- Banaz, E. (2017). Ortaöğretim öğrencilerinin medya okuryazarlığı düzeyleri (Giresun İli örneği), Yüksek Lisans Tezi. Giresun Üniversitesi, Sosyal Bilimler Enstitüsü, Giresun.

- Bergsma, L. J. ve Carney, M. E. (2008). Effectiveness of health-promoting media literacy education: a systematic review. Health education research, 23(3), 522-542.

- $\quad$ Budden, C. B., Anthony, J. F., Budden, M. C. ve Jones, M. A. (2007). Managing the evolution for a revolution: Marketing implications of internet media usage among callege students. https://clutejournals.com/ index.php/CTMS/article/view/5283

- $\quad$ Çam, E., \& Klyıcl, M. (2017). Perceptions of prospective teachers on digital literacy. Malaysian Online Journal of Educational Technology, 5(4), 35-50.

- $\quad$ Fahlevi, R. (2018). Pengaruh film anıması upın dan ıpın terhadap pemerolehan bahasa kedua anak. Kata Pengantar, 129.

- $\quad$ Fidan, M. (2013). Sınıf öğretmeni adaylarının medya okuryazarlık düzeyleri. Erzincan Üniversitesi Eğitim Fakültesi Dergisi, 15(2), 121-137.

- Friesem, Y. (2013). Review: Media literacy in the K-12 classroom. Journal of Media Literacy Education 5(2), 395-396.

- $\quad$ Friesem, Y., Quaglia Beltran, D. ve Crane, E. (2014). Media now: A historical review of a media literacy curriculum. Journal of Media Literacy Education 6(2), 35-55.

- Griffin, P. ve Care, E. (2015). Assessment and teaching of 21st century skills. London: Springer

- Güven, İ. (2004). Fen ve teknoloji öğretmen adaylarının bilgi okuryazarlığı ve medya okuryazarlığı düzeylerinin incelenmesi, Turkish Studie -International Periodical For The Languages, Literature and History of Turkish or Turkic, 9(2), 787-800. https://doi.org/10.7827/TurkishStudies.6395

- Hague, C. ve Payton, S. (2010), Digital literacy across the curriculum, Futurelab. Retrieved from: http:// www.nfer.ac.uk/publications/FUTL06/FUTL06.pdf

- Kartal, O. Y. (2013). Öğretmen adaylarının medya okuryazarlık düzeyleri ile aktif vatandaşlık bağlamında toplum yaşamına katılma düzeyleri arasındaki ilişki. Doktora Tezi. Çanakkale Onsekiz Mart Üniversitesi, Eğitim Bilimleri Enstitüsü, Çanakkale

- Koç, M. ve Barut, E. (2016). Development and validation of New Media Literacy Scale (NMLS) for University Students. Computers in Human Behavior, 63, 834-843.

- Metin, M. (2014). Kuramdan uygulamaya eğitimde bilimsel araştırma yöntemleri. Ankara: Pegem Akademi Yayıncılık.

- Neag, A. (2015). Media literacy and the hungarian national core curriculum - A curate's egg, Journal of Media Literacy Education, 7(1), 35-45. 
- Özer, N., Çelik, S. ve Özatlı, N. S. (2021). Dijital çağda X, Y, Z kuşaklarının medya okuryazarlık düzeylerinin farklı değişkenlere göre incelenmesi: Balıkesir örneği. Kırıkkale Üniversitesi Sosyal Bilimler Dergisi, 11(1), 217-232.

- Semiz, L. (2013). Ortaokul öğrencilerinin medya okuryazarlığı yeterlikleri ve medya okuryazarlığı dersini yürüten öğretmenlerin karşılaştıkları sorunlar. Yüksek Lisans Tezi. Recep Tayyip Erdoğan Üniversitesi, Sosyal Bilimler Enstitüsü, Rize.

- Shopova, T. (2014). Digital literacy of students and its improvement at the university. Journal on Efficiency and Responsibility in Education and Science, 7(2), 26-32.

- $\quad$ Simons, M., Meeus, W. ve T’Sas, J. (2017). Measuring media literacy for media education: Development of a questionnaire for teachers' competencies. Journal of Media Literacy Education, 9(1), 99-115.

- Skills, C. (2003). Literacy in the digital age. Naperville, IL: NCREL.

- Som, S. ve Kurt, A.A. (2012). Bilgisayar ve öğretim teknolojileri eğitimi bölümü öğrencilerinin medya okuryazarlık düzeyleri. Anadolu Journal of Educational Sciences International, 2(1), 104-119.

- Tutkun, T. (2013). Öğretmen adaylarının medya okuryazarlık düzeyi ile aktif vatandaşlık bileşenlerinden temsili demokrasiye, protesto ve sosyal değişime katılım düzeyi arasındaki ilişki. Doktora Tezi. Çanakkale Onsekiz Mart Üniversitesi, Eğitim Bilimleri Enstitüsü, Çanakkale

- $\quad$ Üstündağ, A. (2020). Çocuk ve ekran. Dijital medya ve çocuk gelişimi. Ankara: Eğiten Kitap

- Yazdi, M. (2012). E-learning sebagai media pembelajaran interaktif berbasis teknologi informasi. Jurnal ilmiah foristek, 2(1), 143-152.

- Yazgan, A. D. (2013). Öğretmen adaylarının medya okuryazarlık düzeyleri ile aktif vatandaşlığa ilişkin demokratik değer düzeyleri arasındaki ilişki. Doktora Tezi. Çanakkale Onsekiz Mart Üniversitesi, Eğitim Bilimleri Enstitüsü, çanakkale.

- Y Yldırım, ş. (2017). Türkçe ve sosyal bilgiler öğretmenlerinin medya okuryazarlığı eğitimi ile ilgili becerileri ve görüşleri. Yüksek Lisans Tezi. Yüzüncü Yıl Üniversitesi, Eğitim Bilimleri Enstitüsü, Van.

- Zulkarnain, Z., Heleni, S. ve Thahir, M. (2020). Digital literacy skills of math students through e-learning in COVID-19 era: a case study in Universitas Riau. Journal of Physics: Conference Series, 1663(1), 12-15. 